\title{
Not Known if ROS1 Rearrangement Analysis Was Performed
}

National Cancer Institute

\section{Source}

National Cancer Institute. Not Known if ROS1 Rearrangement Analysis Was Performed. NCI Thesaurus. Code C160468.

An indication that it is not known whether ROS1 rearrangement analysis was performed during the study. 